\title{
Comparative Systematic Risk Analysis: Evidence on the Banking Sector in the United States, Western Europe and South East Asia
}

\author{
Nawazish Mirza and Daniel Danny Simatupang**
}

\section{Introduction}

The basis for asset pricing in financial markets was provided by Bachelier (1900) in his magnificent dissertation "Théorie de la Spéculation" submitted at Sorbonne (Université de Paris). Although from today's perspective, the mathematics and economics he applied were flawed, yet the great genius, Markowitz, declares this early work as an inspiration for his own classical paper of "Portfolio Selection". The risk return relationship has always been a debatable issue in financial theory. "Portfolio Selection" came up with a meaningful measure of quantifying the risk associated with investment; the variance of returns. The equilibrium model of Capital Asset Pricing (CAPM) (Sharpe 1964, Lintner 1965, Mossin 1966) further classified the risk as relevant and irrelevant risk. According to the CAPM, the relevant risk is the systematic risk or non diversifiable risk. The systematic risk is the volatility of returns of a particular stock to the market returns.

Historically, the banking sector is not that active in capital markets. The investors like to invest in deposits and saving accounts more than they would like to go for the stocks of a bank or a financial institution, primarily because of higher risk involved in stock markets. This could be a possible explanation why the banking sector has less representation in stock markets as compared to other sectors. However, the absence of public equity also increases the risk of a bank. The major chunk of assets and liabilities in a bank are of a financial nature. They are subject to interest rate changes and respond quickly to the volatility in the economy. The equity or the share capital acts as a cushion in case of bank's default on its obligations. Due to this utmost importance of equity in a bank, the regulatory authorities have set a standard capital adequacy ratio (see Basle 1988, 1996). This minimum ratio is a

\footnotetext{
* The authors, respectively, have done Masters in Business Administration (MBA) from Lahore School of Economics, Pakistan and Masters in Management from Gadjah Mada University Indonesia, and are currently doing MBA Banking and Finance from Ecole Supérieure des Affaires de Lille, France. They are thankful to Prof Jöel Petey of Ecole Supérieure des Affaires de Lille and Prof Edward Altman of Stern School of Business, New York University.
} 
measure to insure the creditors against any mishap or at least to minimise the possible losses. Similarly, every credit risk management model (Credit Metrics $^{1}, \mathrm{KMV}^{2}$ etc) incorporates the shareholders' equity as an important component.

The sleeping nature of banking stocks makes them an alien in the financial markets. Their sensitivity to economic events makes them more volatile as compared to other industries. Diversification is a tool to minimise the risk and consequently maximise returns. This diversification ${ }^{3}$ could involve investing in different industries or even internationally. Banking stocks could be possible candidates for inclusion in a diversified portfolio. Thus the problem arises as to how these stocks respond to the stock markets and what level of systematic risk they are exposed to in different markets, given certain economic circumstances. The stock markets in the United States, Western Europe ${ }^{4}$ and South East Asia ${ }^{5}$ are the significant stock markets in the world, and based on their different geographic location and economic circumstances, they could be a test case for observing the comparative riskiness of banking stocks in these three different regions.

Historically, the financial sector has been blamed for bubbles, panics and shocks. Leading from Tulip mania to the South East Asian currency crisis, the weaknesses in the banking sector have always been regarded as the main cause for the spread of the financial crises. All these factors make the banking sector more hostile for any investment in their stocks. There are virtually hundreds of studies on systematic risk and its impact on different pricing models, yet the literature is not that vast for systematic risk in international markets. In this study we will estimate the systematic risk in an international environment and test for the riskiness (market risk) of the banking stocks.

The paper is organised as follows. Section-II will provide a theoretical background on systematic risk, CAPM and related concepts. Section-III will describe the possible bias in betas due to emerging market phenomenon and beta correction methods. Section-IV will describe the research methodology, data and model estimation. Section-V will represent data findings and results and Section-VI will conclude the study.

\footnotetext{
${ }^{1}$ See J P Morgan Credit Metrics - Technical Document

${ }^{2}$ KMV Risk Management based on Black, Scholes and Merton's Option Pricing Models.

${ }^{3}$ In this article, we refer to diversification only in stocks.

${ }^{4}$ The countries that adopted Euro as common currency.

${ }^{5}$ We will refer to Indonesia, Malaysia, Thailand, Philippines and Singapore.
} 


\section{Theoretical Perspective}

\section{a. Systematic Risk}

The systematic risk is the volatility of a particular stock or a portfolio to the market. It can be measured by the degree to which returns a given stock tends to move up or down with the market. This tendency of the stock is reflected in its beta coefficient. The beta determines how the stock affects the riskiness of a diversified portfolio, so it is theoretically the most relevant measure of any stock's risk. The concept of systematic, non diversifiable risk or beta was first discussed under the frame work of capital asset pricing model (CAPM), presented by Sharpe. The CAPM framework is very simple under ideal conditions. The model states that the expected returns of an asset are a positive function of three variables: beta, the risk free rate and the expected market return. A simple CAPM equation can be written as

$$
R_{i}=R_{f}+\left(R_{m}-R_{f}\right) \beta_{i}
$$

The above equation of CAPM can be written as a simple time series model that is normally used to estimate betas in the CAPM context. This regression interpretation is

$$
R_{i t}-R_{f t}=\alpha_{i}+\beta_{i} \gamma_{i t}+e_{i t}
$$

where $\gamma_{i t}=R_{m t}-R_{f t}$ and is known as risk premium.

From the above equation, it is evident that systematic risk attributable to its sensitivity to macroeconomic factors is reflected in $\beta_{i}$; non-systematic risk, the unexpected component due to unexpected events that are relevant only to the security, is reflected in $e$. The expected return on an asset depends only on its systematic risk. No matter how much total risk an asset has, only the systematic portion is relevant in determining the expected return on that asset (Corrado and Jordan [2000], p.524).

Another popular model of estimating betas, is the market model or single index model. The studies of stock prices behaviour show that when the market, as measured by a market index, rises most stocks' prices tend to increase. Similarly when the market is on a downside, the stocks in general lose their value. This observation suggests that the reason the stock returns are correlated might be because of common response to the stock market. This correlation could be obtained by relating the return on stock to return on market index. Mathematically this could be expressed as 


$$
R_{i}=\alpha_{i}+\beta_{i} R_{m}+e_{i}
$$

The $\alpha_{i}$ and $e_{i}$ are the components of return of security $i$, and are independent of the market. They are random variables representing the returns insensitive or independent of markets.

Beta is a measure of risk in equilibrium in which investors maximise a utility function that depends on the mean and variance of returns of their portfolio. The variance of returns is a questionable measure of risk for at least two reasons: First, it is an appropriate measure of risk only when the underlying distribution of return is symmetric. Second, it can be applied straightforwardly as a risk measure only when the underlying distribution of returns is normal. However, both the symmetry and the normality of stock returns are seriously questioned by the empirical evidence on the subject.

\section{b. Systematic Risk and CAPM}

The systematic risk or the beta has been in the limelight since its inception in the 1960s. For the last 30 years academicians and practitioners have been debating the merits of CAPM, focusing on whether beta is an appropriate measure of risk. Moreover, the stability of beta has always been a concern in empirical studies. The test of CAPM is the observation of existence of a positive linear relationship between beta and returns. Although the model postulates a positive trade off between beta and expected returns, researchers in general always found a weak but positive relationship between beta and returns over the sample period. Hence, they claimed that the results are inconsistent with the positive linear relationship between beta and returns as prescribed by CAPM and the validity of CAPM is in question, questioning beta as an appropriate measure of systematic risk.

Fama and MacBeth (1973) tested the validity of CAPM using a three step approach. In the first period, individual stocks' betas are estimated and portfolios are formed according to these estimated betas. In the second period, betas of portfolios that are formed in the first period are estimated. In the final step, using data from a third time period, portfolio returns are regressed on portfolio betas (obtained from the second period) to test the relationship between beta and returns. They found a significant average excess return of $1.30 \%$ per month, for the period 1935 through 1968 , a positive relationship exists between beta and monthly returns. They concluded that results support the CAPM in the US stock market and consequently beta is a valid measure of systematic risk. 
However, Schwert (1983) suggested that Fama and MacBeth (1973) only provided a very weak support for a positive risk return trade off since the positive risk return relationship found is not significant across sub periods. Furthermore, when considering seasonal behaviour of their results, the t-statistics for the study period becomes highly suspect and the basic risk return trade off virtually disappears.

Fama and French (1992) studied the monthly average returns of NYSE stocks and found an insignificant relationship between beta and average returns. They concluded that CAPM cannot describe the last 50 years of average stock returns and only market capitalisation and the ratio of book value to market value have significant explanatory power for portfolio returns.

The above mentioned studies give evidence against beta as a useful measure of risk. However, Pettengill et al. (1995) developed a conditional relationship between beta and realised returns by separating periods of positive and negative market excess returns. Using US stock market data in the period 1936 through 1990, they found a significant positive relationship between beta and realised returns when market excess returns are positive and a significant negative relationship between beta and realised returns when market excess returns are negative. This significant relationship is also found when data are divided by months in a year. Furthermore, they found support for a positive risk return relationship. Isakov (1999) followed the approach of Pettengill et al. (1995) and examined the Swiss stock market for the period $1983-1991$. He found supporting results that beta is statistically significantly related to realised returns and has the expected sign. Hence, Isakov (1999) concluded that beta is a good measure of risk and is still alive.

Most of the studies relating to systematic risk have been using the domestic markets. Thus a logical question arises whether the relationship between beta and returns can also be applied to international markets. Does beta have an explanatory power in international equity markets?

To the best of our knowledge, no study (except one) has investigated this issue. Fletcher (2000) examined the relationship between beta and returns in international stock markets between January 1970 and January 1998 using the approach of Pettengill et al. (1995). Using monthly returns of Morgan Stanley Capital International (MSCI) equity indices of 18 countries and the MSCI world index, Fletcher (2000) found that a consistent result exists. There is a significant positive relationship between beta and returns in periods when the world market excess returns are positive and a significant negative relationship in periods when the world market excess returns are negative. Besides, this relationship is symmetric and there is a positive mean excess 
return on the world index on an average. Fletcher (2000) also found that the significant conditional relationship in January exists only in periods of positive market excess returns and the relationship is insignificant in periods of negative market excess returns. The results differ from those obtained from Pettengill et al. (1995) on the US market data.

\section{Bias in Beta Coefficient}

The estimation of beta using the CAPM framework or market model is not difficult. However, there are some issues related to the goodness of the measure. The beta estimates using the above mentioned models will be a suitable measure only if the stocks are actively traded. The active trading in the market helps the beta coefficient to explain the risk associated with the particular stock. One important point to note is that it is not only the stock that has to be traded actively, but also the markets should be active. If, on the contrary, the stock is not actively traded or the markets are thin trading markets, the estimated beta will not be a good estimation of the systematic risk of the stock. This requires correction of estimated betas.

Beta commonly is estimated by using the Ordinary Least Square (OLS). In the OLS model, historical returns on a given security $i$ are regressed against the concurrent returns of the market. Basically, such estimation has a disadvantage because it gives unstable and biased Beta (Scott and Brown [1980]). Biased Beta usually happens in a thin-trading market. Thin-trading phenomenon that results in biased Beta is identical with non-synchronous trading that is caused by infrequent trading. In this sense, there might be some sleeping stocks. Non-synchronous trading problems arise in securities due to the time lag between the setting of market clearing prices for securities and the market index computed at the end of a discrete time interval, known as the intervalling effect (Ariff and Johnson [1990], p.85). Upon pros and cons, the potential for bias in the OLS $\beta \mathrm{i}$ due to non-synchronous trading has been recognised. For securities traded with trading delays different than those of the market, OLS $\beta \mathrm{i}$ estimates are biased. Likewise, for securities with trading frequencies different from those of the market index, OLS $\beta \mathbf{i}$ estimates are biased (Peterson [1989]).

The adjustment to Beta values for non-synchronous trading activities is necessary. Most of the non-synchronous trading phenomenon happens in emerging stock markets because in those markets trade is low (thin). In most practices, not all securities are traded in the same interval, and some of them are not traded for a period of time. If there is no security transaction on a certain day, the security closing price for that day is actually the price from the previous day, which was the price at the last 
time the security was traded. It could be two days ago, three days ago, or may be weeks ago. When the price is used to calculate the market index of a day, the market index actually reflects the trading value of its previous days. If Beta is calculated using returns of a security and returns of a market index formed from security returns from different trading periods, the Beta will be seriously biased (Hartono and Surianto [2000]).

This phenomenon happens in almost all the emerging Stock Exchanges. The major problem is that shares listed on these exchanges are thinly-traded, thus leading to the problem of non-synchronous trading where the market's prices at the end of a period cannot be accurately matched with the prices of a thinly-traded share (Lantara [2000], p.18-19). Consequently, estimates of systematic risk of these shares will be biased. If the estimate of $\alpha \mathbf{i}$ and $\beta \mathbf{i}$ are biased, the estimate of e will also be biased, and the extent of the bias will be more serious for more thinly-traded shares (Ariff and Johnson [1990], p.82).

\section{a. Beta Correction Methods}

In a perfect stock market where prices are continuously formed, the problem of non-synchronous trading should not exist as every stock in the market would have registered a market clearing price at the discrete time of observing the market index, which is the average of all prices at that instant. A significant proportion of the stocks in a market, however, trades so infrequently that prices may be cleared on a few days in a typical month. This is the general behaviour in developing countries. Consequently, the measured market price (and the market return, $R_{m}$ ) deviates from the actual returns had there been continuous trading.

Non-synchronous trading makes beta biased. If the market Beta value obtained from the weighted average of individual Beta values is not equal to one, the adjustment to the Beta values is obviously necessary. There have been many methods suggested by experts to adjust or correct the biased Beta. However, we will use Fowler Rorke method of beta estimation.

Fowler and Rorke (1983) developed a biased Beta correcting method by scaling the coefficients with appropriate weights. The weighting factors to multiply $n$ periods of regression coefficients are calculated as follows:

$$
w_{n}=\frac{1+\rho_{1}+\rho_{2}+\ldots+\rho_{n}-1+\rho_{n}}{1+2 \rho_{1}+2 \rho_{2}+\ldots+2 \rho_{n}}
$$

The values for $\rho_{n}$ are generated from a regression equation as follows: 


$$
R_{m t}=\alpha_{j}+\rho_{1} R_{m t-1}+\rho_{2} R_{m t-2}+\ldots+\rho_{n} R_{m t-n}+e_{t}
$$

The corrected Beta values using Fowler-Rorke method is gained from:

$$
\beta_{t}=w_{n} \beta_{j}^{-n}+\ldots+w_{1} \beta_{j}^{-1}+\beta_{j}{ }^{0}+w_{1} \beta_{j}^{+1}+\ldots+w_{n} \beta_{j}^{+n}
$$

McInish and Wood (1986) examined the adjustment techniques proposed by Fowler-Rorke and found that these techniques reduce a portion of the bias in $\beta_{i}$ arising from thin trading and delays in price adjustments. For some researchers, particularly those who do research in emerging capital markets, the Fowler-Rorke method is believed to be the strongest one in reducing the bias.

Ariff and Johnson (1990) used Fowler-Rorke's three lags and three leads in estimating the corrected Betas at the Singapore Sock Exchange. Hartono and Surianto (2000) found that Fowler-Rorke's four lags and four leads is the best method in correcting Betas on the Jakarta Stock Exchange, after doing several tests with different lags and leads each.

\section{Research Methodology}

As mentioned earlier, our research will test the comparative riskiness of banking stocks in an international context. The market risk will be measured using the portfolio of banking stocks in each geographic market. The three markets that we have chosen are that of the United States, Western Europe (Euro zone) and South East Asia. These stock markets are the significant stock markets in the world, and based on their different geographic location and economic circumstances, they could be a test case for observing the comparative riskiness of banking stock.

United States' financial markets are considered to be safer for investment primarily because of two reasons. The markets are close to strong form efficiency and the tendency of extraordinary profit making is lower. The players in the financial markets can be regarded as somewhat rational compared to other counties. Secondly, the government regulations are strict enough to provide a fair game. They are weaker in emerging markets, especially in Asian markets where either there are no proper guidelines for market trading, or else not practised. Although there have been ups and down in US stock markets such as the Market Crashes of 1929 and 1987, which could be a strong challenge to the being safer proposition, yet the over all situation is better than many of the emerging stock markets. The panics and bubbles have occurred every where but the recovery of the US stock market has been tremendous in 
response to these panics and crashes. The United States' banking sector is also more developed than those in other countries and the banks are more actively traded both on organised and over the counter markets.

The monetary integration of Western Europe has helped to homogenise the economies in these countries. The Euro was launched in the year 2001 but the preparation for a common European currency started from the early 90s. The banking sector in these countries is well monitored and the financial markets are no less than those in the United States. The industrial giants such as Germany and France rely heavily on their banking sectors. However, the evidence shows that in the Euro zone the number of banks listed on the stock exchange, is much lower than that of the United States and all of them that are listed, are not even traded very actively. The banking sector in the Euro zone is less active in stock markets, than that of the United States but is far better than that of Asia. Thus the comparative analysis of risk measure and the performance of banking stocks in the Euro Zone should give us an insight about these stocks in an international reference. An important point to note is that we exclude the United Kingdom and Switzerland because firstly they have not adopted the Euro as a common currency and secondly the banking sector in these two counties have different characteristics than that of Euro countries. The financial sector in Switzerland is more complicated and it requires more factors to analyse it than just systematic risk. Hence, to consider the performance on a regional basis, it could be only possible in the countries that have identical systems and characteristics.

The third geographical region we mentioned is South East Asia ${ }^{6}$. Apart from Japan, generally Asian economies are considered to be a lot more risky. Government intervention in Asian markets, to obtain desired results, is nothing new. The economic policies have a very short life. Personal likings and dislikes of the ruling government translates into regulations without looking into its outcome. All this makes foreign capital escape from a particular economy. An exception to this could be Japan, which is the second biggest economy after the United States. Apart from Japanese markets the second option could be South East Asia. The South East Asian countries have long been known as Asian Tigers. These Asian Tigers share common features in their economies. The banking sector in these countries is weaker than that of the United States or Europe but could be considered better than that of other underdeveloped countries.

\footnotetext{
${ }^{6}$ ASEAN countries \& excluding Japan.
} 
The countries from South East Asia suffered the worst crisis in their history in 1997. The crisis originated by the devaluation of Thailand's currency, the Baht and the period following the devaluation of the Thai Baht witnessed a sudden and unprecedented collapse in asset prices, corporate and financial fragility, and a drastic economic slowdown in East Asian markets. In just over 12 months, the region's stock markets, once among the largest in the world, saw their market capitalisation shrink by as much as $85 \%$ in US dollar terms. Similarly, East Asian currencies depreciated sharply beyond the levels needed to maintain export competitiveness, with some currencies falling by $50-80 \%$ against the US dollar by end 1998. The rapid depreciation in East Asian currencies, coupled with a plunge in asset prices in these countries, led to a fall in real purchasing power as inflationary pressures took root. Concurrently, there was a marked slowdown in economic growth: Asia's real GDP growth declined to $5.8 \%$ in 1997 from $6.6 \%$ in 1996, with a further decline to $4.1 \%$ in 1998 . Emerging markets took on an increasingly high-risk lowreturn profile, as rising volatility and the deterioration in economic fundamentals led to the outflow of capital from these markets.

The financial sector was the most to suffer in this crisis. Many banks were liquidated, taken over by the government or simply were forced to merge. This made the performance of the banking sector in South East Asia more questionable and investors began to avoid investment thereafter in the financial sector. The economies started to recover in 1999, and so also the stock markets but the position of the fragile banking sector is still questionable. Many researchers blame the weaknesses in the financial system for this crisis that spread like a contagion. Given these facts, the question arises as to how the stock market is performing now, has investor confidence developed again? The best observation of the banking sector and its riskiness should be measured by observing the periods in pre crisis, during crisis and post crisis.

To observe the impact of the South East Asian currency crisis on the financial sector and the stock markets, and to avoid a bias in market risk estimation, we need to observe the study period in three periods. These three periods should be pre crisis, during crisis and post crisis. In the pre crisis period the financial markets in South East Asia were performing well and hence their riskiness should be close to that of the United States and Western Europe. During the period when the crisis was at its peak, the risk must have increased significantly and consequently market performance must have been affected. In the post crisis period, the financial sector started to recover, but maybe investor confidence has not fully revived so the markets in South East Asia might still be riskier as compared to the other two. 


\section{Types and Sources of Data}

In every study of international diversification, the first concern is differences in currency. One cannot compare directly a return or a risk from a country's portfolio with another one, if both portfolios are still denominated in each of their own currency (Fletcher [2000]). For this reason, we transform all currencies in the Europe Zone and Asia portfolios into the US dollar at historical spot exchange rate. Hence, we observe the banking portfolios from the point of view of an American investor (Elton and Gruber [1995]).

We will use secondary data, extracted from Data Stream. The data consists of daily closing prices for the selected banking companies and the closing market indices of Morgan Stanley Capital Index (MSCI). The aim is to have one base of market return, so that the return of each portfolio will be reflected from its relation with one specific market. To homogenise the returns in one currency i.e. the US dollar, we will also use the exchange rates of the local currencies, for each of the South East Asian countries, against the US dollar. Similarly during pre Euro period, we will use the exchange rate for every Euro zone country's original currency against the US dollar and lastly the US dollar-Euro exchange rate. All these rates will be on a daily basis.

\section{Criteria Limitation}

During sample selection, we observed there are not many banks listed on the stock exchanges of the countries under consideration. Moreover, some banks have strategic business units that are also listed as a separate entity. These business units are different from the main bank. They normally have small capitalisation and are thinly traded. Their selection in the data could possibly result in bias due to firm size effect. So we exclude all such business units from our research. Hence only the parent banking company is selected from the whole banking group. This limitation was more intense while selecting stocks in the banking sector from Euro zone countries. In the case of the United States and South East Asia the constraint was somewhat limited. The banks that are more into advisory services and investment banking like Morgan Stanley, Goldman Sachs and Merrill Lynch are also excluded from the research despite their higher capitalisation that is, at times, greater than some of the European and Asian banks.

To be eligible for inclusion as a sample, each company had to meet the following criteria: 
1. The company must be a public limited banking company, listed on NYSE, organised exchanges of Euro zone and organised exchanges of South East Asia from March 1994 until March 2003.

2. The company must be transacted on the above mentioned stock exchanges and must have a complete record of daily prices.

The period of continued listing is important because we divide our study into three periods, namely pre crisis, crisis and post crisis, for beta estimation and its comparison. Many banks from South East Asia went bankrupt during the period of crisis and hence are excluded from the sample. The final sample included 30 banking companies from each region. All these banks have similar capitalisation in purchasing power parity terms. Similarity in capitalisation is required to avoid a possible bias that might arise due to firm size effect. The research has shown that size to book value ratio is an important factor in determining the risk profile of a company. During the financial crisis in South East Asia some high performing banks were forced to be liquidated as they were not able to sustain the economic pressure. There were about a hundred banks that were liquidated during the crisis. Though these banks performed very well in the pre crisis era but as they ceased to exist after the crisis. They are excluded from the sample.

\section{Econometric Limitations}

Whenever beta is estimated there are certain conceptual problems associated with the estimation. We will present three most basic econometric issues related with betas.

1. The systematic risk or beta estimates are based on ex-ante risk premiums, which are not directly observable. These estimates are based on rational expectations for an investor. Under rational expectations, the realised rates of return on assets in a given time period are drawings from the ex-ante probability distributions of returns on those assets. However, no logical justification can be given that investors will be rational over time.

2. Betas are normally estimated using linear regression. The underlying assumption for these estimates is the normal distribution of returns. However, in reality the normality of returns is not necessary.

3. The third major problem relates to the observation of the proxy of market portfolio. In fact, many assets are not marketable and the proxies used for return on market portfolios exclude major classes of assets such as human capital, private businesses and private real estate. The most common 
assumption used to overcome this problem is by assuming that the disturbance terms from regressing the asset returns, on the return of the market proxy portfolio, are uncorrelated with the true market portfolio and that the proxy portfolio has a unit beta. If the market proxy is a portfolio constructed from the individual assets or portfolios contained in the test sample, this assumption is equivalent to assuming that the market proxy is the minimum variance unit beta portfolio of the set of all feasible portfolios constructed from the assets in the test sample.

\section{Estimation of Beta Coefficients}

We will use two methods to estimate the beta coefficient. The first one in by using Ordinary Least Square (OLS) regression or the single index model, and the second one is with the Fowler-Rorke method. These two methods, however, are not applied to all portfolios. The OLS will only be applied to Europe and the United States portfolio, because both markets are matured markets and have no significant sleeping stocks phenomenon. The FowlerRorke method will be applied exclusively for the Asian market, due to considerations of non-synchronous trading, sleeping stocks, and emerging markets.

Elton and Gruber (1995) clearly explore that in a good portfolio, the Alpha and Beta respectively, must be statistically significant, equal to zero and one. Thus, first we will test the betas and alphas generated by both methods for all portfolios. This is aimed to have a clearer overview about the robustness of results. equation (3),

The single index model used for estimation of beta will be similar to

$$
R_{i}=\alpha_{i}+\beta_{i} R_{m}+e_{i}
$$

The returns $R_{i}$ and $R_{m}$ will be calculated using the logarithmic approach. The daily returns will be of the form

$$
\begin{aligned}
& R_{i d}=\ln \left[\frac{P_{i d}}{P_{i d-1}}\right] \text { where } \mathrm{P}_{\mathrm{id}} \text { and } \mathrm{P}_{\mathrm{id}-1} \text { are prices on day } d \text { and } d-1 . \\
& R_{m d}=\ln \left[\frac{M S C I_{\text {reg } X, d}}{M S C I_{\text {regX }, d-1}}\right] \text { where } M S C I_{\text {reg } X, d} \text { is Morgan Stanley Capital }
\end{aligned}
$$

Index on day $d$ and $d-1$ for either region Europe, Asia or the United States. 
For South East Asian banking stocks we will use the Fowler-Rorke biased Beta correction method, with several tests using: (1) three lags and three leads, (2) four lags and four leads, and (3) five lags and five leads. The final objective is to determine the criterion that best estimates market Beta value i.e. closest to one (see Fowler and Rorke 1983).

The Fowler-Rorke method can be established by first calculating the weighting factors. The formula is as follows:

$$
w_{n}=\frac{1+\rho_{1}+\rho_{2}+\ldots+\rho_{n-1}+\rho_{n}}{1+2 \rho_{1}+2 \rho_{2}+\ldots+2 \rho_{n}}
$$

The values for $\rho_{n}$ are generated from a regression equation as follows:

$$
R_{m t}=\alpha_{i}+\rho_{1} R_{m t-1}+\rho_{2} R_{m t-2}+\ldots+\rho_{n} R_{m t-n}+e_{t}
$$

The corrected Beta values using Fowler-Rorke method is generated from:

$$
\beta_{t}=w_{n} \beta_{i}{ }^{-n}+\ldots+w_{1} \beta_{i}{ }^{-1}+\beta_{i}{ }^{0}+w_{1} \beta_{i}{ }^{+1}+\ldots+w_{n} \beta_{i}{ }^{+n}
$$

The $n$ value is among three, four, and five to test: (1) three lags and three leads, (2) four lags and four leads, and (3) five lags and five leads. The criterion that gives a market Beta value closest to one will be used in calculation.

\section{Hypotheses}

According to the general perception the hypothesis to be tested is that, based on systematic risk, Asian banking stocks are the riskiest followed by that of Western Europe and the United States. The hypotheses (alternative) tested are

» For the period March 1994 - June 1997 (Pre Crisis Period)

$$
\begin{aligned}
& H_{1}: \beta_{E}-\beta_{A} \neq 0 \\
& H_{2}: \beta_{E}-\beta_{U S} \neq 0 \\
& H_{3}: \beta_{U S}-\beta_{A} \neq 0
\end{aligned}
$$

》 For the period July 1997 - December 2000 (During Crisis) 


$$
\begin{aligned}
& H_{4}: \beta_{E}-\beta_{A} \neq 0 \\
& H_{5}: \beta_{E}-\beta_{U S} \neq 0 \\
& H_{6}: \beta_{U S}-\beta_{A} \neq 0
\end{aligned}
$$

» For the period January 2001 - March 2003 (Post Crisis)

$$
\begin{aligned}
& H_{7}: \beta_{E}-\beta_{A} \neq 0 \\
& H_{8}: \beta_{E}-\beta_{U S} \neq 0 \\
& H_{9}: \beta_{U S}-\beta_{A} \neq 0
\end{aligned}
$$

The subscripts in the term signify countries: US for United States, E for Euro zone and A for South East Asia.

\section{Data Findings and Results}

The returns and beta coefficients are estimated according to the subperiods of hypothesis:

1. March 1994 until end of June 1997 for the pre-crisis period.

2. July 1997 until end of 2000 for the crisis period.

3. January 2001 until end of March 2003 for the post-crisis period.

The following Table presents the mean beta for all the periods using Fowler Rorke for Asian portfolio while OLS for Euro Zone and United States.

Table 1: Beta for all Regions and all Periods

\begin{tabular}{lcccc}
\hline \multicolumn{5}{c}{ One-Sample Statistics } \\
\hline & $\mathbf{N}$ & Mean & Std. Deviation & Std. Error Mean \\
\hline BETAEUR1 & 30 & .1175533 & .082481220 & .015058942 \\
BETAEUR2 & 30 & .34660033 & .329572304 & .060171395 \\
BETAEUR3 & 30 & .53008933 & .683933177 & .124868543 \\
BETAUS1 & 30 & .06197900 & .169317182 & .030912947 \\
BETAUS2 & 30 & .42748233 & .369086530 & .067385673 \\
BETAUS3 & 30 & .57382200 & .420150011 & .076708546 \\
BASIA1FR & 30 & 1.168208 & .953923916 & .174161882 \\
BASIA2FR & 30 & 3.093616 & 2.078689525 & .379515048 \\
BASIA3FR & 30 & 1.101129 & .940943826 & .171792053 \\
\hline
\end{tabular}


164 The Lahore Journal of Economics, Vol.9, No.1

Note that in Table 1 above, the period 1, 2, and 3 signify the precrisis, crisis, and post-crisis periods, respectively, and EUR, US, and ASIA signify the regions. The Fowler Rorke method used was 5 Leads and 5 Lags instead of 3 Leads and 3 Lags and 4 Leads and 4 Lags because the calculations resulted in beta significantly close to 1 in 5 Leads and 5 Lags than the other two.

The following table presents the mean difference hypotheses for systematic risk using t test approach.

Table 2: Mean Systematic-Risk Differences Significance Test

Panel A: Beta Europe minus Asia

\begin{tabular}{|c|c|c|c|c|c|c|}
\hline & $\mathbf{F}$ & Sig. & $\mathbf{T}$ & $\begin{array}{c}\text { Sig. } \\
\text { (2-tailed) }\end{array}$ & $\begin{array}{c}\text { Mean } \\
\text { Difference }\end{array}$ & Std. Error \\
\hline \multirow[t]{2}{*}{ BT1EAFR } & 66.71086 & $3.21 \mathrm{E}-11$ & -6.61542 & $1.29323 \mathrm{E}-08$ & -1.156452417 & 0.174811707 \\
\hline & & & -6.61 & & & \\
\hline \multirow[t]{2}{*}{ BT2EAFR } & 53.36427 & $9 \mathrm{E}-10$ & -7.148 & $1.64752 \mathrm{E}-09$ & -2.747 & 473 \\
\hline & & & -7.14893 & $5.43796 \mathrm{E}-08$ & -2.747015744 & 0.384255473 \\
\hline \multirow[t]{2}{*}{ BT3EAFR } & 3.473773 & 0.067413 & -2.68878 & 0.009346834 & -0.571039493 & 0.212378583 \\
\hline & & & -2.68878 & 0.00956684 & -0.571039493 & 0.212378583 \\
\hline
\end{tabular}

Panel B: Beta United States minus Asia

\begin{tabular}{cccccc}
\hline & & & Sig. & Mean & \\
F & Sig. & T & \multicolumn{1}{c}{ (2-tailed) } & \multicolumn{1}{c}{ Difference } & Std. Error \\
\hline BT1AUFR 53.67778 & 8.29E-10 & -6.25398 & $5.1778 \mathrm{E}-08$ & -1.10622875 & 0.176884062 \\
& & -6.25398 & $6.11492 \mathrm{E}-07$ & -1.10622875 & 0.176884062 \\
BT2AUFR 50.69467 & $1.84 \mathrm{E}-09$ & -6.91692 & $4.04118 \mathrm{E}-09$ & -2.666133744 & 0.385451035 \\
& & -6.91692 & $9.60118 \mathrm{E}-08$ & -2.666133744 & 0.385451035 \\
BT3AUFR 21.49694 & $2.06 \mathrm{E}-05$ & -2.80273 & 0.006878453 & -0.527306826 & 0.188140135 \\
& & -2.80273 & 0.007766899 & -0.527306826 & 0.188140135 \\
\hline
\end{tabular}

Panel C: Beta Europe minus United States

\begin{tabular}{|c|c|c|c|c|c|c|}
\hline & $\mathbf{F}$ & Sig. & $\mathbf{t}$ & $\begin{array}{l}\text { Sig. (2- } \\
\text { tailed) }\end{array}$ & $\begin{array}{c}\text { Mean } \\
\text { Difference } \\
\end{array}$ & Std. Error \\
\hline \multirow[t]{2}{*}{ BETA1EU } & 7.052121 & 0.010205 & 1.460594 & 0.149523083 & 0.050223667 & 0.034385782 \\
\hline & & & & 2518 & 0.050 & 782 \\
\hline \multirow[t]{2}{*}{ BETA2EU } & 0.587638 & 0.446443 & 0.895301 & 0.374327071 & $0.080 \&$ & 0609 \\
\hline & & & 0.895301 & 0.374373927 & 0.080882 & 0.090340609 \\
\hline \multirow[t]{2}{*}{ BETA3EU } & 14.4213 & 0.000352 & 0.298418 & 0.766450318 & 0.043732667 & 0.146548129 \\
\hline & & & 0.298418 & 0.766667608 & 0.043732667 & 0.146548129 \\
\hline
\end{tabular}

*Note that 1,2 , and 3 signify the periods. 
As we can see from Table 2, all results lead us to reject our null hypotheses. The negative mean difference in Panel A of Table 2 shows that the risk of Asian banking stocks is greater than European ones, and all are statistically significant at $p=1 \%$. The same result is also established in Panel $B$, where risk of Asian region banking stock is greater than that of the United States market, and all are significant. The comparison between Europe and United States markets gives a risk in European portfolio rather than in that of the United States but significance is very low. The F-test shows great significance for Panel A and Panel B. This means that variances of beta in Panel A and Panel B are statistically not equal and each beta stands on its own variance. However, the F-test in panel $\mathrm{C}$ is not significant in comparison between Europe and the United States in the crisis and the post crisis period. The Mann-Whitney $U$ non-parametric test confirms all these results.

Table-3: Mann Whitney Non Parametric Test

\section{Panel A Europe and Asia}

\begin{tabular}{llll}
\hline & BT1EAFR & BT2EAFR & BT3EAFR \\
\hline Mann-Whitney U & 90.000 & 43.000 & 259.000 \\
Wilcoxon W & 555.000 & 508.000 & 724.000 \\
Z & -5.322 & --6.017 & -2.824 \\
Asymp. Sig. (2-tailed) & .000 & .000 & .005 \\
\hline
\end{tabular}

where EAFR is Europe and Asia Fowler Rorke.

Panel B Asia and United States

\begin{tabular}{llll}
\hline & BT1EAFR & BT2EAFR & BT3EAFR \\
\hline Mann-Whitney U & 105.000 & 54.000 & 282.000 \\
Wilcoxon W & 570.000 & 519.000 & 747.000 \\
Z & -5.101 & -5.855 & -2.484 \\
Asymp. Sig. (2-tailed) & .000 & .000 & .013 \\
\hline
\end{tabular}

where AU is Asia FR and United States.

Panel C. Europe and United States

\begin{tabular}{llll}
\hline & BT1EAFR & BT2EAFR & BT3EAFR \\
\hline Mann-Whitney U & 375.000 & 396.000 & 387.000 \\
Wilcoxon W & 840.000 & 861.000 & 852.000 \\
Z & -1.109 & -.798 & -.931 \\
Asymp. Sig. (2-tailed) & .268 & .425 & .352 \\
\hline
\end{tabular}

where EU is Europe \& United States 
From the Mann Whitney U test it is evident that European and US's banking stocks are significantly less risky than that of Asia, for all periods, pre, crisis and post. While the US Banking sector appeared to be less risky than that of the Euro Zone's, but this fact is not significant in statistical terms. These findings are in line with those we observed before. Thus we reject our null hypotheses and conclude that Asian stocks are the most risky followed by European and US stocks. These findings are significant at the $5 \%$ level of significance.

In order to test whether the three mean betas (independent sample) are not equal we further perform the Kruskal Wallis Test. The mean betas were found to be significantly different from each other. The following table summarises the result for the Kruskal Wallis non parametric test.

Table-4: Kruskal Wallis Chi Square Test

\begin{tabular}{|c|c|c|c|}
\hline \multicolumn{4}{|c|}{ Ranks } \\
\hline & REGIONS & $\mathbf{N}$ & Mean Rank \\
\hline \multirow[t]{4}{*}{ BETA1 } & Europe & 30 & 33.37 \\
\hline & Asia & 30 & 60.53 \\
\hline & United States & 30 & 42.60 \\
\hline & Total & 90 & \\
\hline \multirow[t]{4}{*}{ BETA2 } & Europe & 30 & 40.23 \\
\hline & Asia & 30 & 50.27 \\
\hline & United States & 30 & 46.00 \\
\hline & Total & 90 & \\
\hline \multirow[t]{5}{*}{ BETA3 } & Europe & 30 & 44.53 \\
\hline & Asia & 30 & 36.10 \\
\hline & United States & 30 & 55.87 \\
\hline & Total & 90 & \\
\hline & BETA1 & BETA2 & BETA3 \\
\hline Chi-Square & 16.775 & 2.229 & 8.649 \\
\hline df & 2 & 2 & 2 \\
\hline Asymp. Sig. & .000 & .328 & .013 \\
\hline
\end{tabular}

where 1, 2 and 3 represent the three periods as used previously.

Our test statistics resulted in rejection of our null hypotheses and support our alternative hypotheses. The beta of banking stocks from Asia was found significantly higher than that of Western Europe and the United States. This is again similar to what we obtained initially. The Chi square statistics clearly specify that there is no mean difference between the three 
samples. However, the significance is quite low in the case of the United States vs. Western Europe. All the beta estimates were significant at $p=1 \%$. It would be interesting to observe the beta values of the banking portfolio for the three periods under consideration. The mean beta for the Euro Zone during the pre crisis period was around 0.01 . Now if we consider the CAPM framework the beta estimate, which is close to zero, makes the portfolio return equal to a risk free rate. The equilibrium return in the presence of such beta would be slightly higher than that of risk free rate prevailing in the economy. Similarly beta in the US for this period was 0.06 , giving a similar observation of banking portfolio for the period. In Asia, as demonstrated by our statistics, the beta was significantly greater than one. One possible explanation for this phenomenon could be better prudential practices in the United States and Western Europe for the banking sector than in South East Asia.

In the period, when the crisis was at its peak, the beta for all three markets increased. Some studies have shown that the crisis in South East Asia not only affected the domestic economies but the fear of the spread of crisis like a contagion produced concerns in foreign economies including the United States and Western Europe. The beta of Asian banking stocks was around 3 and it is a clear picture of what was happening to the banking sector in the ASEAN countries.

In the post crisis era, as is evident from the empirics above, the Asian stocks recovered. However the stocks of the United States and Western Europe became more risky. In fact this period was the post September 11 era so investment was risky. This period could be termed as the crisis period for especially the United States and to some extent Western Europe. Like all of Wall Street, banking stocks also suffered and a high risk profile emerged.

\section{Conclusion}

This study was aimed at testing the comparative riskiness of banking stocks in three different geographic markets. The theory of finance suggests that the systematic risk is the only relevant risk for which the investor is rewarded. There are many factors that contribute to the systematic risk both at the macro and micro levels. In an international environment the systematic risk becomes more relevant as it also includes country specific factors such as country risk, exchange rate risk etc. The banking sector is like the backbone of the economy of any country and surprisingly the number of banks traded, on organised or over the counter markets, is low. They also face the phenomenon of thin trading due to investors' low 
interest in their shares. The analysis was based on the performance of banking stocks in the stock market. We compared the systematic risk for three regions. South East Asia was hit by one of the worst financial crisis in 1998. This crisis badly affected the economy of the Asian region. The financial sector was the most to suffer. Many banks were liquidated or were taken over by the government as they were unable to sustain the pressure created by the crisis. Some of the banks literally went bankrupt overnight. The failure of central banks to handle the crisis added fuel to the fire.

However, during this era, the banking stocks in EU and the US were performing normally. Hence we divided the study period into three different periods. The pre crisis era when there was no abnormality, the era of crisis when the South East Asian sector was on fire and the post crisis era when the banking sector started to recover. In the post crisis era the events of September 11 took place making Western markets more risky for investments. Our empirical results, as reported, support our notion of risk profiles of the three regions. We reject our null hypothesis for Asia vs. US and Asia vs. Europe concluding that Asian banking stocks were more risky than those of EU and the US. However, the results for Europe vs. US were not significant. These observations were supported by Kruskal Wallis Chi square and Mann Whitney test at the 5\% level of significance. The mean beta estimates for the three periods indicate that banking portfolio of Asian stocks, during the crisis, was thrice as risky as that of the market. Moreover the beta estimate for the US and EU increased significantly in the post crisis period. The possible explanation for this phenomenon could be the events of WTC making investment in the stock market more risky. The less than one beta portfolio in the United States and Western Europe make them a strong candidate for investment.

However we feel that in order to have more insight into the issue, performance of the stocks using event study methodology, must be observed. Do these stocks outperform or underperform the market in the three periods and to what extent? This phenomenon requires further explanation and could be a possible issue for further research. 


\section{References}

Altman, Jacquillat and Levassuer, 1974, "Comparative Analysis of Risk Measures: France and United States," Journal of Finance 29, No 5, December, pp. 1495-1511.

Amihud, Yakov, and Haim Mendleson, 1986, "Asset Pricing and the Bid-Ask Spread," Journal of Financial Economics 17, No.2, December, pp. 223-250.

Bachelier, L., 1900, "Théorie de 1a Spéculation", Annales de l'Ecole Normale Supérieure de Paris.

Baese1, Jerome B, 1990, "On the Assessment of Risk: Some Further Consideration," Journal of Finance 29, No. 5, December, pp. 14911494.

Banz, Rolf W., 1981, "The Relationship between Returns and Market Value of Common Stocks," Journal of Financial Economics 9, No. 1, March, pp. 3-18.

Barnes, Pau1, 1986, "Thin Trading and Stock Market Efficiency: The Case of the Kuala Lumpur Stock Exchange," Journal of Business Finance and Accounting, Winter, pp. 609-617.

Bartholdy, Jan, and Allan Riding, 1994, "Thin Trading and the Estimation of Betas: The Efficacy of Alternative Techniques," Journal of Financial Research 17, No. 2, Summer, pp. 224-254.

Basu, Sanjoy, 1983, "The Relationship between Earnings Yield, Market Value, and Return for NYSE Common Stocks: Further Evidence," Journal of Financial Economics 12, No. 1, June, pp. 129-156.

Berglund, Tom, Eva Liljeblom, and Anders Loflund, 1995, "Estimating Betas on Daily Data for a Small Stock Market," Journal of Banking and Finance, March, pp. 41-64.

Bergstrom, Gary L., 1975, A new route to higher returns and lower risks, Journal of Portfolio Management, pp. 30-38.

Berry, Michael A., George W. Gallinger, and Glenn V. Henderson Jr., 1987, "Adjusting for Nonsynchronous Data: How Important is It ?," Akron Business and Economic Review, Winter, pp. 52-56. 
Bhardwaj, Rawinder K. and LeRoy D. Brooks, 1992, "Stock Price and Degree of Neglect as Determinants of Stock Returns," Journal of Financial Research 15, No. 2, Summer, pp. 101-112.

Black, Fischer, 1973, "Yes, Virginia, There Is Hope: Tests of the Value Line Ranking System," Financial Analysts Journal 29, No. 5, Sept/Oct, pp. 10-14.

Blume, E. Marchall, 1971, "On the Assessment of Risk," Journal of Finance 6, No. 1, March, pp. 1-10.

Blume, Marshall E., and Robert F. Stambaugh, 1983, "Biases in Computed Returns: An Application to the Size Effect," Journal of Financial Economics 12, No. 3, November, pp. 387-404.

Brown, K.C., W.V. Harlow, and S.M. Tinic, 1988, "Risk Aversion, Uncertain Information, and Market Efficiency," Journal of Financial Economics 22, pp. 355-385.

Corrado, C. and Jordan, B., 2000, "Risk Aversion, Uncertain Information, and Market Efficiency: Re examining the Evidence," Review of Quantitative Finance and Accounting 8, pp. 51 - 68.

Dimson, Elroy, 1979, "Risk Measurement When Shares are Subject to Infrequent Trading," Journal of Financial Economics 7, June, pp. 197-226.

Erb, Claude, Campbell, Harvey \& Viskantas, 1994, Forecasting International Correlation. Financial Analysts Journal, 50, No.6 (Nov/Dec). pp. 32-45

Fama, Eugene F., 1970, "Efficient Capital Markets: A Review of Theory and Empirical Work,” Journal of Finance 25, No. 2, May, pp. 383-417.

Fama, Eugene F., 1991, "Efficient Capital Markets: II," Journal of Finance 46, No. 5, December, pp. 1575-1617.

Fama, Eugene F., and Kenneth R. French, 1988, "Permanent and Temporary Components of Stock Prices," Journal of Political Economy 96, April, pp. 24-73.

Fama, Eugene F, and Kenneth R. French, 1992, "The CAPM is wanted, Dead or Alive," Journal of Finance 54, pp 1947-1958. 
Fama, E., and MacBeth, J., 1973, "Risk, Return and Equilibrium: empirical tests. Journal of Political Economy, 81, pp. 607-636.

Fieltz, Bruce, 1974, "Indirect versus Direct Diversification," Financial Management 3, No. 4 (Winter) pp. 54-62.

Fletcher, J., 2000, "On the Conditional Relationship between Beta and Return in International Stock Markets". International Review of Financial Analysis, 9, pp.235-245.

Fowler, David J., and C. Harvey Rorke, 1983, "Risk Measurement When Shares are Subject to Infrequent Trading: Comment," Journal of Financial Economics 12, August, pp. 279-283.

Grubel, G. Herbert., 1968, Internationally Diversified Portfolios : Welfare Gains \& Capital Flows, American Economic Review 58, pp. 1299-1314

Hartono, Jogiyanto, and Surianto, 2000, "Bias in Beta Values and Its Correction: Empirical Evidence from the Jakarta Stock Exchange," Gadjah Mada International Journal of Business 2, No. 3, September, pp. 337-347.

Isakov, D., 1999, "Is Beta Still Alive? Conclusive Evidence from the Swiss Stock Market”. The European Journal of Finance, 5, pp. 202-212.

Jaffe, Jeffrey, Donald B. Keim, and Randolph Westerfield, 1989, "Earnings Yield, Market Values, and Stock Returns," Journal of Finance 44, No. 1, March, pp. 135-148.

Klemkosky, Robert, and John Martin, 1975, "The Adjustment of Beta Forecasts," Journal of Finance 10, No. 4, September, pp. 1123-1128.

Kritzman, Mark, 1991, "What Practitioners Need to Know About Regressions," Financial Analysts Journal 47, No. 3, May/June, pp. 12-15.

Lakonishok, Josef, Andrei Shleifer, and Robert W. Vishny, 1994, "Contrarian Investment, Extrapolation, and Risk," Journal of Finance 49, No. 5, December, pp. 1541-1578.

Lakonishok, J., and Shapiro, A. C., 1986, "Systematic Risk, Total Risk, and Size as Determinants of Stock Market Returns”. Journal of Banking and Finance, 10, pp 115-132. 
Levy, Haim and Marshall Sarnat., 1970, "International diversification of investment portfolios”. American Economic Review, 60, pp. 668-692.

Lintner, J., 1965, The valuation of risk assets and the selection of risky investments in stock portfolios and capital budgets, Review of Economics and Statistics 47, 13-37.

Markowitz, H., 1952, Journal of Finance, "Portfolio Selection," March pp. 77-91.

Mossin, J., 1966, Equilibrium in a capital asset market, Econometrica 34, 768-783

Pettengill, G. N., Sundaram, S., and Mathur, I., 1995, "The Conditional Relation between Beta and Returns”. Journal of Financial and Quantitative Analysis, 30, pp. 101-116.

Poterba, James, and Lawrence Summers, 1988, "Mean Reversion in Stock Prices: Evidence and Implications," Journal of Financial Economics 22, No. 1, October, pp. 27-59.

Reinganum, Marc R., 1981, "A new Empirical Perspective on the CAPM". Journal of Financial and Quantitative Analysis, 16, pp 439-462.

Scholes, Myron, and Joseph Williams, 1977, "Estimating Betas from Nonsynchronous Trading," Journal of Financial Economics 5, December, pp. 307-328.

Schwert, G. William, 1992, "Size and Stock Returns, and Other Empirical Regularities," Empirical Research in Capital Markets, ed: G. William Schwert and Clifford W. Smith, Jr., $1^{\text {st }}$ ed. San Francisco: McGrawHill, Inc.

Scott, Elton, and Stewart Brown, 1980, "Biased Estimators and Unstable Betas," Journal of Finance 35, No. 1, March, pp. 49-55.

Solnik, B., C. Boucrelle and Y. Le Fur., 1996, "International Market Correlation and Volatility," Financial Analysts Journal 52 September/October. pp 17-34.

Sharpe, W., 1964, "Capital Asset Prices: A Theory of Market Equilibrium under Conditions of Risk" Journal of Finance, 33, pp. 885 - 901. 
Susiyanto, Muh. Fendi, 1997, "Market's Overreaction in the Indonesian Stock Market,” Kelola 6, No. 16, pp. 88-100.

Tandelilin, Eduardus, 1997, "Determinants of Systematic Risk: The Experience of Some Indonesian Common Stock," Kelola 6, No. 16, pp. 101-115.

Vasicek, Oldrich, 1973, "A Note on Using Cross-Sectional Information in Bayesian Estimation of Security Betas," Journal of Finance 8, No. 5, December, pp. 1233-1239. 